\title{
SLIS Connecting
}

Volume 6 | Issue 2

Article 6

2017

\section{Protection Versus First Amendment Violation: Self- Censorship as it Relates to Youth and Young Adult Services}

Ann M. Baillie

University of Illinois at Urbana-Champaign, annb2@illinois.edu

Follow this and additional works at: https://aquila.usm.edu/slisconnecting

Part of the Archival Science Commons, Collection Development and Management Commons,

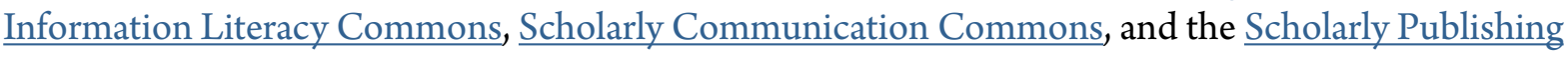
Commons

\section{Recommended Citation}

Baillie, Ann M. (2017) "Protection Versus First Amendment Violation: Self-Censorship as it Relates to Youth and Young Adult Services," SLIS Connecting: Vol. 6 : Iss. 2 , Article 6.

DOI: $10.18785 /$ slis.0602.06

Available at: https://aquila.usm.edu/slisconnecting/vol6/iss2/6

This Article is brought to you for free and open access by The Aquila Digital Community. It has been accepted for inclusion in SLIS Connecting by an authorized editor of The Aquila Digital Community. For more information, please contact Joshua.Cromwell@usm.edu. 


\section{Protection Versus First Amendment Violation: Self-Censorship as it Relates to Youth and Young Adult Services}

By Ann Baillie, The iSchool at Illinois

\section{Introduction}

Within the library profession, the ability to protect patrons' first amendment rights is a point of pride. As the American Library Association (ALA) Code of Ethics explains, "[librarians] uphold the principles of intellectual freedom and resist all efforts to censor library resources" (ALA, 2008). Librarians have a history of standing up against censorship and fighting for the rights of readers. They put up posters and pass out bookmarks to celebrate Banned Books Week. Librarians think they are the defenders of the first amendment. The profession condemns external censorship threats, such as requests to remove copies of Mark Twain's The Adventures of Huckleberry Finn from the National Association for the Advancement of Colored People or demands from Mel and Norma Gabler to change the contents of textbooks in Texas (Kravitz, 2002).

In reality, the ability of librarians to fight censorship is complicated and limited by the practice of self-censorship. Self-censorship is when librarians choose to censor their own library collections. It occurs when a librarian chooses not to purchase an item because it contains controversial material, or when a librarian chooses to label or restrict access to an item. It can happen in any kind of library and impacts patrons of all ages. It is a violation of the ALA's Code of Ethics. Worst of all, it diminishes the value of the work done by librarians to fight censorship, as librarians and other information science professionals are less likely to talk about self-censorship.

Though self-censorship impacts all patrons, its potential impact on youth and young adult services is of particular importance, as how children are treated by librarians will impact how these patrons view libraries for the rest of their lives.
Thus, this literature review will focus on the practice of self-censorship among youth services, young adult, and school librarians. The history of self-censorship in youth services librarianship, which contributes to the selfcensorship in contemporary practices, will be reviewed. Studies showing that modern selfcensorship is on the rise will be discussed and examined. Such studies often debate if current practices are truly self-censorship, or a necessary reactionto the growing amounts of violence, sex, and swearing in children's and young adult literature; thus, the claim that literature is becoming darker will be examined.

\section{History of Self-Censorship}

Although self-censorship in librarianship as a concept has negative connotations today, it used to be a common, even expected practice in library science. As the number of libraries grew in the early 20th Century, librarians saw their job as being protectors of knowledge and culture, rather than the more general duty of providing access to all pieces of information. This often led to librarians refusing to select a book they saw as low-quality literature, regardless of its popularity. The highly popular dime novels of the late 19th Century, which provided the action and suspense "young readers wanted, all for a dime" were often not purchased by "librarians and teachers [who] attacked the alleged power of dime novels to corrupt morals" (Kravitz, 2002, p. 40).

Later, in the 1930s, the Nancy Drew and The Hardy Boys detective series became so popular among children that they began to outsell the Bible. Despite this, the Nancy Drew books were continually placed on a "Not Recommended list" for librarians, as they were not considered "serious fiction" (Wiegand, 2015, p. 150-151). 
According to library science theory, the job of a librarian is to allow access to information and materials, especially to books as popular as dime novels Nancy Drew, and The Hardy Boys were at their times of publication. The fact that the books were not "serious fiction" should not have had an impact on the librarian's decision to purchase the books.

More recently, librarians have also refused to buy or keep books based on the book's portrayal of minority groups. At the 1971 ALA Midwinter meeting, police officers criticized librarians for being "quick to comply with requests to remove ... [Helen Bannerman's] Little Black Sambo" over its depiction of AfricanAmericans, but refusing to "remove William Steig's Sylvester and the Magic Pebble" even though it was offensive to police (ALA, 2010, p. 109). In 2000, a school librarian pushed for Caroline Cooney's The Terrorist (1997, Scholastic) to be removed from the school's library because she and a student believed "the book offensively stereotyped the Islamic faith" (Kravtiz, 2000, p. 129). Technically, a librarian should not refuse to buy a book because he or she disagrees with its contents. Yet, librarians repeatedly do so.

All of these instances of self-censorships are based on the same belief: the librarian believes that he or she knows what is best for children. The librarians who engaged in self-censorship believed that children could not tell the difference between "serious fiction" and entertainment, between moral and immoral actions, or recognize racism and Islamophobia. According to ALA, it is not the job of any librarian - even a youth services librarian - to decide what a child can or cannot handle. As ALA (2010) explains, "Parents have the right and responsibility to guide the reading... choices of their own children. Library staff cannot assume that parental authority" though they can help children and their families make decisions about reading choices (p. 8).
By engaging in self- censorship, these librarians overstepped their professional responsibilities and "[assumed] that parental authority" reserved only for parents and legal guardians.

Although self-censorship was much more accepted in the past than it is today, it was not accepted by everyone. In his 1953 article "Not Censorship but Selection," Lester Asheim does not use the actual phrase self-censorship. He does, however, describe the difference between selecting materials, a key part of the library science profession, and censorship. Librarians cannot buy every material created for their collections, due to limited physical space and monetary resources (Asheim, 1953). Librarians have the duty, then, to put their limited resources to the best possible use for the communities they serve through selection. Yet: many librarians have been known to defer to anticipated pressures and to avoid facing issues by suppressing possible issue-making causes. In such cases, the rejection of the book is censorship, for the book has been judged ... in terms of the librarian's devotion to three square meals a day. (Asheim, 1953, p. 67)

As Asheim suggests, when the librarian's desire to have "three square meals a day" and stay employed causes the user's intellectual freedom to be violated, censorship has occurred. The fact that the decision to censor was made by a librarian, however, can make the act of censorship more difficult to notice than if an outside group was trying to censor a book.

In 1959, Marjorie Fiske wrote Book Selection and Censorship: A Study of School in Public Libraries in California. Fiske's study found that self-censorship was more or less likely to occur depending on a librarian's beliefs about the ideological role of the library science profession and his or her "philosophies of librarianship" (Fiske, 1959, p. 16). 
Self-censorship was thought, at the time, to be on the rise because "'Everything the library stands for... [ran] counter to the prevailing trends'" of the 1950s, especially the growing fear and hatred of Communism under the House Un-American Activities Committee (Fiske, 1959, p. 10-11).

Fiske (1959) also found that librarians existed on a continuum with quality as one extreme and demand as the other. Librarians had to try to find the balance between creating high-quality collections or demand-based collections built around what patrons wanted to read. Librarians "with restrictive attitudes toward controversial materials are found on the demand side of the continuum," as opposed to those who were quality focused (Fiske, 1959, p. 12). The impact of beliefs about what the philosophical role of a librarian, as well as the desire to meet patron demand, still impacts self-censorship today.

\section{Contemporary Self-Censorship Research Studies}

Unfortunately for the library and information science profession, the practice of selfcensorship is increasing. It is difficult to know exactly how many cases of self-censorship occur in the United States each year. ALA only keeps track of "written challenges to library books and materials," so self-censorship cases cannot be counted, as there is no paper documentation (Whelan, 2009, p. 27).

Wendy Rickman, a professor at the University of Central Arkansas, studied the practice of selfcensorship among school librarians in 2006, which was published in School Library Research: Research Journal of the American Association of School Librarians (2010). Though it is impossible to know how similar the practice of selfcensorship among school librarians is to that among youth service librarians at public libraries, it can be assumed that there is at least some similarity between the two groups, as they both work with the same kinds of books and the same age patrons. The study found that "[as] a whole, the responding school librarians ... were not inclined to self-censoring of materials" (Rickman, 2010, p. 15).
Yet, Rickman (2010) also found that selfcensorship did exist, especially among certain groups. Librarians between "the [ages] 60-69" were more likely to self-censor than younger librarians, librarians without a "formal collegiate education degree" more so than librarians with formal training, librarians who work at high schools rather than elementary or middle schools, and librarians with "15 or fewer years" of work experience as opposed to those with more experience (p. 15).

The School Library Journal (SLJ) and the National Coalition Against Censorship (NCAC) were also able to measure the practice among school librarians in two studies, the first in 2008 and an updated study in 2016. The key finding of the 2016 updated SL/NCAC study was that the amount of self-censorship is rising rapidly among school librarians, even between 2008 and 2016. According to the study, over ninety percent of elementary and middle school librarians, as well as seventy-three percent of high school librarians engage in self-censorship by refusing to buy a book due to its content (SL Research, 2016a). Additionally, other kinds of self-censorship are also growing, such as the use of labels.

Content labels are used to warn patrons about a book's contents, such as that a book contains sex or violence. The ALA (2010) declared labeling to be censorship and "opposes labeling as a means of predisposing people's attitudes toward library materials" in Labeling and Rating Systems: An Interpretation of the Library Bills of Right ( $p$. 155). Yet, labeling is on the rise in school libraries. In 2008, ten percent of elementary school librarians, eighteen percent of middle school librarians, and six percent of high school librarians practiced labeling. By 2016, those numbers rose to twenty-seven percent, thirtythree percent, and eleven percent, respectively. Thus, the practice of labeling is growing, despite ALA warnings that it "[predisposes] people's attitudes" about books (SLJ Research, 2016a, p. 8). 
These two studies are intriguing, as they are in direct contrast with one another. Rickman's study and the SLJ/NCAC study came to essentially opposite conclusions. There are a few possible reasons for this. First, the two studies surveyed slightly different groups of people. Rickman (2010) only surveyed school librarians in Arkansas, Delaware, and North Carolina. SL Research (2016a) instead surveyed school librarians from across the United States. The discrepancy could exist because censorship could occur less often in these states than in other states.

The SLJ/NCAC study did find that the likelihood of facing an external challenge varies slightly by region; about forty-nine percent of school librarians on the west coast face challenges, but only thirty-eight percent of New England school librarians do (SLJ Research, 2016a). More importantly, the studies occurred ten years apart. The vastly different conclusions could also reflect changes in publishing over the past decade. SL Research (2016a) found that approximately twenty-nine percent of school librarians "find [themselves] weighing the effect of the controversial subject matter more often now than [they] did one or two years ago" (p. 5). If the number of librarians placing increased importance on the impact of controversial subject matter could increase by almost one third in only two years, it is possible for the number of librarians to increase from less than half to over ninety percent in a decade.

\section{Changes in Publishing}

The previously mentioned SL/NCAC study also published comments from study participants about the reasons they chose to self-censor. Though the comments featured a variety of motivations, one reason for self-censorship was clearly the most common: changes in publishing. One librarian explained, "I think teen books are much more graphic than they were a few years ago. Before it was considered horrible if it had the 'F-word' once, and now some books have it multiple times on every page" (SL Research, 2016a, p. 5). Another commented, "Adult level controversial subject matter is making its way into literature for younger readers" (SLJ Research, 2016b).
Librarians who work with children's and young adult literature are noticing a change in the content. Though there are disagreements about the impact of this change (some librarians think the change is positive and will start important conversations, others think the change will force children to confront information that they do not have enough life experience to truly understand), librarians are united in agreement over the rise of mature content.

There is evidence in the books themselves that contemporary "teen books are much more graphic than" previous teen and young adult books. This can be seen by comparing the number of instances of possible reasons for selfcensorship in three teen books spanning the early 1980s to the present. In 1983, Francine Pascal wrote Double Love (Cloverdale), the first book in the Sweet Valley High series that Dan Weiss, a publisher at St. Martin's Press, uses as an example of the beginning of teen commercial fiction (Brown, 2011). The novel follows twins, Jessica and Elizabeth Wakefield, as they fight over Todd Wilkens, a popular football player on whom both twins have a crush.

In 1999, Stephen Chobsky's The Perks of Being a Wallflower (MTV Books) became a cult classic. The novel is a series of letters from unpopular Charlie, as he works through his first year of high school and becomes friends with Sam and Patrick. The Perks of Being a Wallflower was the \#1 Young Adult Best Seller on the New York Times Best Sellers list for December 16, 2012, the first week the New York Times tracked the sales of Young Adult novels separately (New York Times, 2012). Published in 2017, Angie Thomas' The Hate U Give (HarperCollins) tells the fictional story of Starr, an African-American teenager who is in the car when her friend - an unarmed African-American male teenager - is shot and killed by a police officer during a traffic stop. The book has received critical acclaim and was the \#1 Young Adult Best Seller on the New York Times Best Sellers list the week of April 9, 2017. 
Though not at all a complete picture of the path of young adult publishing, it does give a general picture of how the industry has changed over time. Each book was written about twenty years apart, and each was commercially popular. Each book was read and evaluated for the number of instances that might cause a librarian to selfcensor. These reasons were then grouped into categories. For example, every time sexual assault was discussed in The Perks of Being a Wallflower, it was noted and counted. Sex and sexual activity were divided into two categories. "Non-descriptive" refers to times when sex and sexual activity was referenced or discussed, but the author does not give explicit details about what is happening. "Descriptive" refers to instances when the author has provided enough explicit details that the reader can visualize what is happening.

Swearing was also divided into two categories. "Mild words" are more common swear words that could be said on broadcast television, such as hell or damn. "Intense words" are less socially acceptable swear words that could not be said on television, such as fuck or racial epithets. For both sexual activity and swearing, two categories were created because a librarian could find the milder version acceptable but still want to self-censor in more intense cases. Additionally, if an incident fell into multiple categories, it was counted in both categories. For example, a descriptive sexual assault would be counted as both "sexual assault" and "sex and sexual activity (descriptive)" (Figure 1). The same standards were held to each book.

Figure 1, while again not an overall picture of young adult publishing, does suggest that there are more instances of potential reasons for selfcensorship in more recent books than in less recent books. Double Love had the most instances of a potential reason in only one category, illegal drag racing. The Perks of Being a Wallflower had the most instances in ten categories, while The Hate $U$ Give had the most instances in sixteen categories. While this does show that teen books are becoming edgier, it also shows in many cases the number of instances depends on the book's topic. The Perks of Being a Wallflower, for example, featured more instances of homosexuality and homophobia than The Hate $U$ Give in large part because Perks is about coming to terms with one's sexuality, something with which The Hate $U$ Give is not concerned.

This trend of the rise in mature content is causing another argument within the debate over how to combat self-censorship. Some youth services librarians question whether refusing to buy a title because of the maturity level of the content qualifies as self-censorship. Refusing to buy a book due to content seems to be the most basic definition of self-censorship. As Asheim wrote in 1953, if a librarian "[defers] to anticipated pressures... the rejection of the book is censorship" (p. 67). If a librarian follows this historic and clearly thought logic, not purchasing a book because it is thought to be "too mature" for children is censorship.

Yet, the librarians who decide to not purchase some books argue that they are not doing so out of fear. These librarians point out that part of their job is to make wise selection materials, which includes evaluating if a book is ageappropriate. As one librarian argued in response to the SLJ/NCAC study:

Not selecting a book because it is not ageappropriate is not censorship, with all its ugly connotations. It's why they pay me: to make informed decisions. Censoring is not buying [Cris Beam's] I am J for a high school (i.e. ageappropriate) library because you don't like the content. (Trav45, 2016)

By this librarian's logic, knowing what different ages want to read about and are capable of understanding is not censorship, but part of the job. So, while a high school or young adult librarian refusing to buy I am J would be considered censorship, an elementary, middle school, or youth services librarian would be making a good selection decision. 
There is some evidence within the fields of both library and information science and publishing that supports this argument. Children's publishing companies, such as Capstone Press and Scholastic, have their books' recommended grade levels clearly displayed on their websites. Public libraries typically keep picture books, easy readers, children's chapter books, young adult books, and adult books in separate sections.
Deciding if a book is best for a children's section or the young adult section is part of a youth services librarian's job. The $S L$, one of the most important and trusted review journals for school, youth service, and young adult librarians, includes grade level recommendations in its reviews. Reviews from multiple journals, however, are not always in agreement about the best age for a book.

Figure 1. Reasons for Self-Censorship

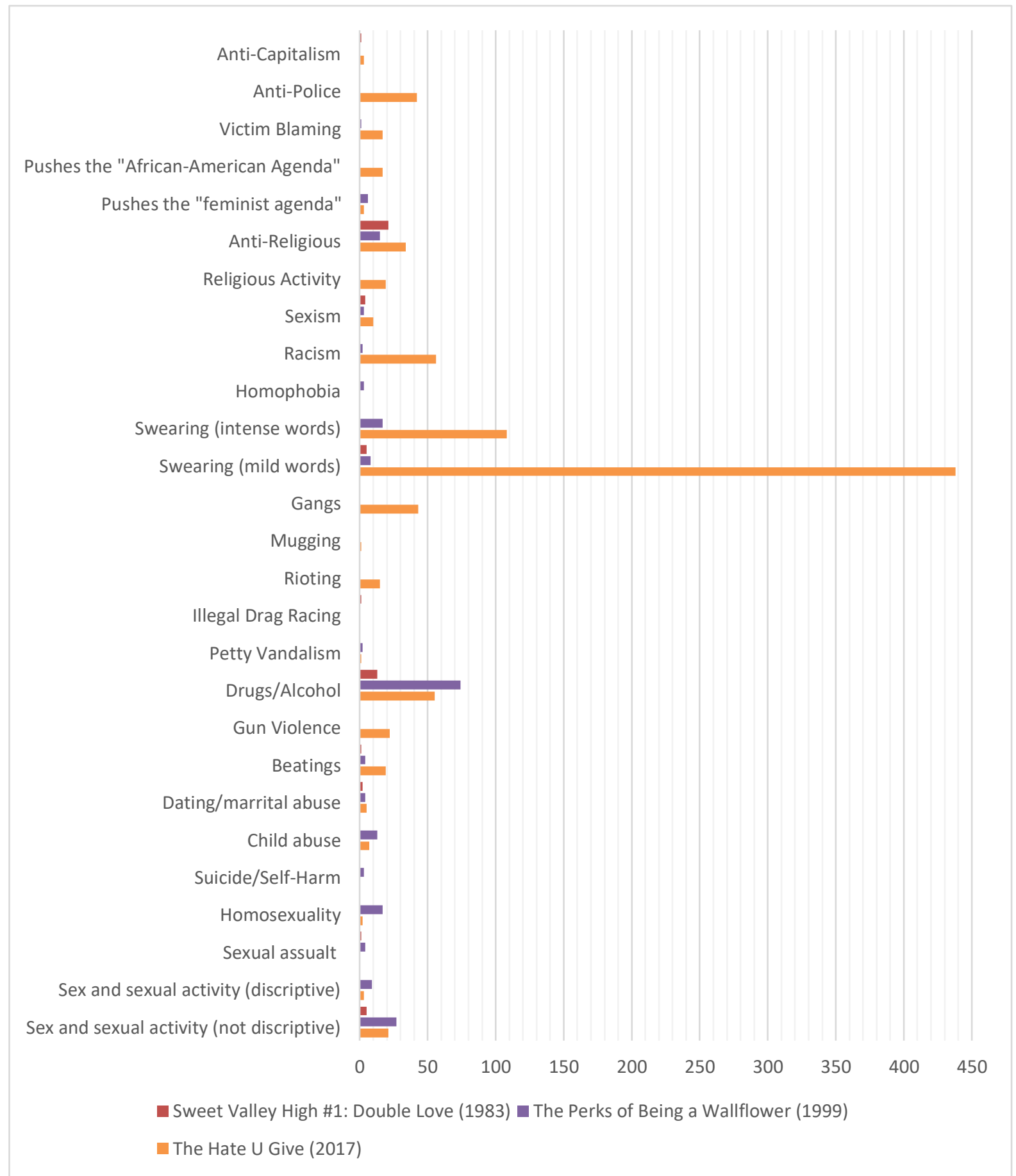


One book, "Ellen Wittlinger's Sandpiper" (Simon and Schuster, 2012), for instance, was recommended for grades eight to twelve by Booklist, ages twelve and up by Publishers Weekly, and grades nine and up by SLJ (Whelan, 2009). In this case, a middle school librarian who does not purchase the book would not be practicing self-censorship if he or she was following the $S L J$ review but would be practicing self-censorship according to Publishers Weekly.

The ALA, however, notes that these decisions, while a necessary part of the job, can become instances of self-censorship if done for the wrong reasons. The association:

believes strongly that young people are entitled to freely access ideas and information, subject only to limitations imposed by their parents or legal guardians ... Limiting access ... does not protect the young from the complex and challenging world that confronts them, but it can deprive them of information that is important to them or even vital for their learning and development as maturing persons. (ALA, 2010)

The ALA's perspective depends on the view of librarianship as a job based on providing access so that patrons, no matter their age, can learn about the subjects that interest them. The librarians who believe that and decide to not purchase a book due to age-appropriateness, however, view their job more similarly to the librarians of the early 20th Century who did not buy dime novels and Nancy Drew because they were thought to be not appropriate. In part, then, the debate over if such actions constitute selfcensorship depends upon the perspective of the librarian, as Fiske (1959) noted in her research.

\section{The Blurring of Young Adult and Adult Books} This debate over the age-appropriateness of books is complicated by the publishing industry. The publishing industry agrees with ALA's belief that children being able to access information is "vital for their learning and development as maturing persons."
The industry has publicly acknowledged that their books are becoming more mature. As authors and publishing companies have publicly explained, adult and young adult novels have become more interconnected as genres. Kate Axelrod's The Law of Loving Others (2015), for example, was intended by the author for an adult audience because of its "subject matter and the fact that the book was peppered with both casual drug use and casual sex," but Penguin wanted to market the book as YA (Axelrod, 2016). Then, when the book was published, the largest criticism was that the book was too adult. The backlash against the book's content was so strong that the paperback edition had a redesigned cover "hoping to attract a more adult audience this time around" (Axelrod, 2016).

Though it is impossible to know exactly how effective the marketing change was, Barnes and Noble (2017), one of the largest booksellers in the United States, still labels The Law of Loving Others for readers ages fourteen to seventeen. Situations such as the one surrounding the best age group for The Law of Loving Others pose a difficulty for librarians concerned with selfcensorship. Axelrod did not intend for teens to read the book. The publishing house originally wanted teens to read the book, but then reconsidered the idea. Reviewers typically thought the book was better for adults, but bookstores continued to market the book within their stores as YA. So, is the book for teens or adults? More importantly, if a young adult or high school librarian does not buy the book believing it is an adult book, is that librarian engaging in selfcensorship, or correctly categorizing the book and realizing that most teens would be uninterested in the text?

Axelrod is not alone in facing confusion over whether a book is meant for teens or adults. Barry Lyga faced a similar problem with his 2009 novel Boy Toy (Houghton Mifflin Harcourt) about a sexual relationship between a twelve-year-old boy and his teacher. 
Lyga "expected" book bannings and angry letters, "but none of those things ever happened," as "adults weren't letting [kids] get the book (Whelan, 2009, p. 27). Partly, this was due to reader's and store's interpretation of the book. Though Boy Toy received excellent reviews, "some bookstores were placing the novel in the adult section" (Whelan, 2009, p. 27). Again, is placing the book in the adult section self-censorship on the part of the bookstores? Or, did the shop owners make a reasonable monetary decision, believing that adults would be more likely than teens to purchase a book about sexual abuse?

Both bookstores and publishing companies, after all, do ultimately make decisions about what age will most enjoy a book based on how the company thinks it can best sell the book. Libraries, though they do not make money, also organize books based on where the librarian believes it will get the most circulation and select books based on the best use of funds. In theory, if a book will be of most interest to teens, it should be marketed by the publishing company as a YA title, and then sold in bookstores and housed in libraries in the YA section. Yet, as Axelrod's The Law of Loving Others and Lyga's Boy Toy show, this does not always happen. The problem becomes even more complex, however, when the data of how and to whom young adult books are sold are taken into account.

Young adult books, after all, are a key part of book sales. As literary agent Meredith Barnes believes, young adult books "[are] publishing's closest thing to a safe bet in years," creating over three billion dollars in sales in 2009 alone (Brown, 2011). Clearly, the genre of teen books is popular. However, while the books are popular amongst teens, teens are not the main consumers of YA books. "Understanding the Children's Book Consumer in the Digital Age... an ongoing biannual study from Bowker Market Research" funded by the largest publishing houses found in 2012 that most YA books are actually purchased by adults ("New Study", 2012).
About fifty-five percent of those who buy young adult books are ages eighteen and over; twentyeight percent of buyers are between the ages of thirty and forty-four. Additionally, these readers are buying the books for their own enjoyment about seventy-eight percent of the time, as opposed tobuying the book to give to a child. In other words, young adult novels actually reach adults more than they reach teens, their target audience. Those who work in the book creation and distribution businesses are aware of the attraction between adults and young adult books. Lyga, for example, once joked that "his fan base was made up of "15-year-old-boys and women in their 30s and 40s'" (Benedetti, 2011, p. 42). The fact that adults are interested in and buying young adult books has not gone unnoticed.

Less clear, however, is how this has impacted the books themselves. According to publishers, there has been no impact. When selecting manuscripts, they claim to "always [think] of [their] core readers of true teenagers and whether a book will be interesting to them" (Brown, 2011). If this is true, there is no need for confusion - young adult books are for young adults, and adults happen to like them. For the authors who write the books, however, the line between "core readers of true teenagers" and adults is much less clear. For one thing, authors themselves are more likely to be writing for multiple ages. Authors such as Holly Black, Kathy Reichs, and Adriana Trigiani have published books marketed at adults as well as books marketed at teens, while James Patterson has written for adults, teens, and middle-graders, as well as a picture book (Benedetti, 2011).

Authors do not usually see a difference in writing for teens or adults. As David Leviathan, a young adult author popular among both teens and adults explains, "I don't really delineate between a teen reader and an adult reader--they both want the same things" (Benedetti, 2011, p. 42). From an artistic standpoint, this makes sense the job of an author is to write a book, hopefully, one that people will want to read, so there is no need to adjust how a book is written. 
From both a practical library and information science perspective, however, there is the issue that "15-year-old boys and women in their 30s and 40s" are two different groups of people most likely to be in two different sections of the library. If a book like Boy Toy is marketed for young adults but is mostly read by adults, where should the book be shelved? By putting it in the adult section, is a librarian committing selfcensorship, or simply giving the book to the group of people statistically most likely to read it?

The problem becomes even more complicated when considering the motivations adults have for reading young adult books - popularity. Some have suggested that "adults buy YA because they perceive everyone else as buying YA" (Brown, 2011). According to this logic, what attracts adult readers to a young adult book is not always the book itself but that "they perceive everyone else" as reading the entire genre of young adult books. Thus, putting a book like Boy Toy in the adult section of the library might actually make it less likely that adults would read the book, and would, therefore, be considered self-censorship because it would limit access to the book. The dilemma to figure out how to make a book as popular as possible is an old dilemma, dating back to the 1950s. As one librarian explained in Fiske's (1959) study, the librarian' s "job is to get the borrower of a book together with what he wants ... there's no alternative, really, because no one will take what he doesn't want, and then circulation would go down" (p. 13).

\section{Growing Fear and Parental Outrage}

One solution that librarians use to solve these

difficult problems is thinking about the motivation of the librarian when making selection decisions. Using motivation to determine if an instance was self-censorship or a good selection decision is an old and trusted idea in library and information science - this is why "the rejection of the book is censorship, for the book has been judged" on the librarian's fear rather than on the book itself (Asheim, 1953, p. 67).
To an extent, this solution can be applied to possible self-censorship cases in public and school libraries. If a librarian decides not to purchase a book out of fear that someonewill complain, that decision clearly qualifies as selfcensorship. As Wisconsin librarian Megan Schliesman (2007) recalls, "I [remember] what l'd learned in a workshop... 'How Far is Too Far: Pushing the Boundaries in Young Adult Literature.' That day opened my eyes... to the very real fears and concerns that librarians... have about facing challenges" ("Self-Censorship: Let's Talk").

As both Asheim and Schliesman note, librarians depend on making good selection decisions in order to keep their jobs. If a librarian consistently chooses books that the community does not like or agree with, it is likely that the librarian would lose his or her job. This fear is not new, and has grown so large that the Freedom to Read Foundation (FTRF) started the LeRoy C. Merritt Humanitarian Fund in 1970 to give "short-term, immediate assistance" to those whose "positions are jeopardized or lost as a result of defending intellectual freedom" (ALA, 2010, p. 27).

Theoretically, this fund, along with work done by the ALA's Office of Intellectual Freedom (OIF), should give librarians the confidence to buy books that are of high quality, even if there are concerns that the content may not be ageappropriate.

The Merritt Humanitarian Fund and the ALA's work, however, does not seem to be having a great impact lessening fears, at least among youth services, young adult, and school librarians. If it was, the SLJ/NCAC study would not have found that over ninety percent of elementary and middle schoollibrarians and seventy-three percent of high school librarians are engaging in self-censorship (SLJ Research, 2016a). This could partly be caused by librarians not knowing the Merritt Humanitarian Fund exists or how to contact the ALA for help in the event of an intellectual freedom-related job problem. 
Rickman (2007), after all, did find that librarians without training were more likely to engage in self-censorship, and it would be difficult for a librarian to know about the FTRF or the ALA's OIF without some degree of training (p. 15). However, since most schools require a librarian to have some degree of training and most public libraries require candidates to either hold or be working towards a Master in Library and Information Science degree, it is likely that librarians without any training are a small portion of the total librarian population.

A larger portion of the problem, most likely, is the growing opinion among librarians and authors who work with children and teens that people are more likely to complain about content today than they did in the past. Granted, there have always been complaints about books' contents. The National Association of Women (NOW) once "led Texas to remove five dictionaries from its list of approved textbooks" due to the dictionaries being viewed as sexist by the organization (Kravtiz, 2002, p. 14). As far back as 1915, the Protestant "Watch and Ward Society in Boston... read and [evaluated] current fiction... Booksellers caught selling 'dirty' and 'sinful' books were prosecuted under the Massachusetts obscenity statute" (Kravitz, 2002, p. 9).

Additionally, the amount of actual book challenges has gone down between 2008 and 2016. In the SLJ/NCAC 2008 study, approximately forty-nine percent of librarians faced an actual book challenge (Whelan, 2009). By 2016, that number had decreased to around forty-two percent (SLJ Research, 2016). Since books have always been challenged, and the number of actual challenges is decreasing, it is somewhat unclear what makes librarians feel like they face a greater likelihood of being challenged now than they would have twenty years ago.

Yet, this is how librarians and authors feel. As one librarian explained in the SLJ/NCAC study, "Everyone is offended by everything these days...so I weigh how I will defend the book before it is even challenged" (SLJ Research, 2016a, p. 5).
Another believes that "there seems to be more people censoring" books, while a third noticed "heightened tensions (sometimes by parents) around these topics" presented in children's and young adult books (SLJ Research, 2016b). Judy Blume, a highly popular and often censored young adult author, also believes that people will now challenge more kinds of content than they did previously. She tells other writers, "You think you're safe? Think again, because when you're writing, anything can be seen as dangerous'" (Whelan, 2009, p. 25). It seems to be this fear of "[being] seen as dangerous" that drives both librarians to self-censor their collections and authors to self-censor their works. As one librarian noted in response to the 2016 SLJ/NCAC study, "No librarian wants to be branded publicly as a corrupter of youth. That is what we're up against" (Jacobson, 2016, p. 22-23). Although unintuitive, the fear of being challenged is causing the number of challenges to decrease, especially as books for children and teens continue to contain more mature content. As librarians read the books, they discover the adult content within the books and fear that the book will be challenged. To avoid dealing with the challenge, many librarians choose to self- censor and not include the book in their collections or put them in the adult section. This causes the number of books in the collection that are likely to be challenged to decrease, thus leading to a decrease in challenges.

\section{Conclusion}

As the School Library Journal / National Coalition Against Censorship shows, self-censorship among youth and school librarians is on the rise. Though self-censorship has always been an issue in the library science profession, the practice seems to be growing now because books for youth and young adults are becoming more mature. Though this is not an excuse for selfcensorship, it does raise the question as to what qualifies as self-censorship. Young adult books are mainly purchased by adults, and though it is clear the books are becoming more mature, it is unclear if this purchase rate means young adult books are really "for" adults, despite the book's advertising. 
Yet, it is the growing fear of these books' content and a lack of training that causes librarians to self-censor collections, even with the best of intentions. Despite the uncertainty over how much mature content should be in a youth book, or if there are some conditions under which not buying a book because it is inappropriate for the age group is not self-censorship, one thing is certain: if librarians and information science professionals do not talk more openly about selfcensorship, these issues will not be resolved.

\section{References}

ALA. (2008). Code of ethics of the American Library Association. American Library Association. Retrieved from www.ala.org/advocacy /proethics/codeofethics/codeethics.

ALA. (2010). Intellectual freedom manual (8th edition.). Chicago: American Library Association.

Asheim, L. (1953). Not censorship but selection. Wilson Library Bulletin, 28, 63- 67.

Axelrod, K. (2016). The time my grown-up novel was marketed as young adult: On the ever-blurring lines across literary genres. LitHub. Retrieved from http://lithub.com/the-time-my-grown-up-novel-wasmarketed-as- young-adult/.

Barnes \& Noble (2017). The law of loving others. Barnes \& Noble. Retrieved from www.barnes andnoble.com/w/the-law-of-loving-others-kateaxelrod/1119671295\#productInfoTabs.

Benedetti, A. (2011). Not just for teens. School Library Journal, 136(11), p. 40-43. Retrieved from www.slj.com/2011/06/teens-ya/not-just- for-teens-a35-going-on-13-special/.

Brown, D.W. (2011). How young adult fiction came of age. The Atlantic. Retrieved from

www.theatlantic.com/entertainment/archive/2011/0 8/how-young- adult-fiction-came-of-age/242671/.

Chbosky, S. (1999). The perks of being a wallflower. New York: MTV Books.
Fiske, M. (1959). Book selection and censorship: A study of school and public libraries in California. Berkeley: University of California Press.

Jacobson, L. (2016). Unnatural selection. School Library Journal, 62(10), p. 20-24.

Retrieved from www.slj.com/2016/09/censor ship/unnatural- selection-more-librarians-selfcensoring/.

Kravitz, N. (2002). Censorship and the school library media center. Westport, CT: Libraries Unlimited.

New York Times. (2012). Best sellers: Young adult. New York Times. Retrieved from www.nytimes.com/books/bestsellers/2012/12/16/young-adult/.

New York Times. (2017). Best sellers: Young adult. New York Times. Retrieved from www. nytimes.com/books/best- sellers/2012/12/16/youngadult/.

Pascal, F. (1983). Sweet valley high: Double love. New York: Laurel-Leaf Books.

Publishers Weekly. (2012). New study: 55\% of YA books bought by adults. Retrieved from www.publishersweekly.com/pw/by-topic/ childrens/childrens-industry-news/article/53937new-study-55-of- ya-books-bought-by-adults.html.

Rickman, W. (2010). A study of self-censorship by school librarians. School Library Research, 13.

Retrieved from www.ala.org/aasl/sites/ ala.org.aasl/files/content/aaslpubsandjournals Lslr/vol13/SLR StudyofSelf-Censorship V13.pdf.

Schliesman, M. (2007). Self-censorship: Let's talk about it. Cooperative Children's Book Center. Retrieved from https://ccbc.education.wisc.edu/ freedom/selfcensorship.asp.

SL Research (2016a). Controversial book survey. Retrieved from www.slj.com/features/selfcensorship/. 
SL Research (2016b.). SLJ controversial books survey responses: Weighing subject matter. School Library Journal. Retrieved from www.slj.com /2016/09/censorship/slj-controversial-books-surveyresponses-weighing-subject-matter/.

Thomas, A. (2017). The hate u give. New York: Blazer + Bray.

Trav45. (2016). Comment on Unnatural selection: More librarians are self-censoring. School Library Journal. Retrieved from www.slj.com/2016/09/censorship/unnaturalselection-more- librarians-self-censoring/.

Whelan, D. L. (2009). A dirty little secret: Selfcensorship is rampant and lethal. School Library Journal, 55(2), 27-30. Retrieved from www.slj.com/2009/02/censorship/a-dirtylittle-secret-self- censorship/.

Wiegand, W. A. (2015). Part of our lives: A people's history of the American public library. Oxford: Oxford University Press. 